\title{
Differences in the Expression of Heat- Shock Proteins and Antioxidant Enzymes between Human and Rodent Pancreatic Islets: Implications for the Pathogenesis of Insulin-Dependent Diabetes Mellitus
}

\author{
Nils Welsh,* Boris Margulis,* L. A. Håkan Borg,* \\ Helena Jernberg Wiklund, ${ }^{\dagger}$ Johan Saldeen,* Malin Flodström,* \\ Maria Alice Mello,* Arne Andersson,* Daniel G. Pipeleers, ${ }^{\neq}$ \\ Claes Hellerström,* and Decio L. Eizirik* \\ *Department of Medical Cell Biology, Uppsala University, Uppsala, \\ Sweden \\ ${ }^{\dagger}$ Department of Pathology, University Hospital, Uppsala University, \\ Uppsala, Sweden \\ ${ }^{\ddagger}$ Department of Metabolism and Endocrinology, Vrije Universiteit \\ Brussels and B-cell Transplant, Brussels, Belgium
}

\begin{abstract}
Background: It has previously been observed that the insulin-producing cells of human pancreatic islets are more resistant to alloxan-, streptozotocin-, nitroprusside-, or cytokine-induced injury than those of mouse and rat islets. Materials and Methods: Human pancreatic islets were obtained from heart-beating organ donors. The expression of the stress proteins heat shock protein 70 (hsp70) and heme oxygenase and the anti-apoptosis gene bcl-2 was determined in isolated rat, mouse, and human islets, either cultured in vitro or transplanted under the kidney capsule of nude mice, using immunoblot analysis. Rat and human islet sensitivity to hydrogen peroxide was assessed by glucose oxidation measurements. Isolated islets were also analyzed for their catalase and superoxide dismutase activities, and the islet cell levels of reduced glutathione were determined in response to hydrogen peroxide and nitroprusside. Programmed cell death in human and rat islets in response to streptozotocin was evaluated using TUNEL staining.

Results: Cultured human islets expressed higher contents of hsp70 than mouse and rat islets at basal condi-
\end{abstract}

tions. Also after 4 weeks under the kidney capsule of normoglycemic mice, the hsp70 levels were higher in human islets than in rat islets. The expression of another stress protein, heme oxygenase (HO), was strongly increased in cultured rat islets, but was not affected in human islets. Expression of the bcl-2 gene could not be detected in human islets. In spite of this, $0.5 \mathrm{mM}$ streptozotocin induced apotosis in rat but not in human islet cells. Hydrogen peroxide ( 0.1 and $0.4 \mathrm{mM})$ decreased glucose oxidation rates in rat but not in human islets. The levels of reduced glutathione were moderately decreased in human and rat islet cells and sharply decreased in mouse islet cells in response to hydrogen peroxide. Moreover, the activities of catalase and superoxide dismutase (SOD) were markedly lower in mouse islets than in human islets. The activity of catalase was lower in rat islets than in human islets.

Conclusion: Human islets differ clearly from mouse and rat islets in their increased expression of hsp70, catalase, and SOD, which may explain the increased resistance of human islets to $\beta$ cell toxins.
Address correspondence and reprint requests to: Nils Welsh, Department of Medical Cell Biology, Biomedical Center, P.O. Box 571, S-751 23 Uppsala, Sweden.

\section{INTRODUCTION}

The sensitivity of the pancreatic $\beta$ cell to noxious agents may be an important determinant in the pathogenesis of insulin-dependent diabetes mel- 
litus (IDDM) $(1,2)$. More specifically, it has been proposed that the clinical manifestation of IDDM is preceded by a prediabetic period characterized by a gradual loss of the $\beta$ cell mass (3). During this period, $\beta$ cell death has been suggested to be accelerated by factors such as nitric oxide (NO), oxygen free radicals, alkylating substances, viruses, and cytokines $(3,4)$. We have recently observed major species differences between human and rodent pancreatic islets in the susceptibility to some of these agents, both in vitro and in vivo $(2,5)$. Thus, human islets displayed a lower sensitivity to a combination of cytokines (interleukin-1 $\beta$ [IL-1 $\beta]+$ tumor necrosis factor $\alpha$ [TNF $\alpha$ ] + interferon- $\gamma$, an NO donor (nitroprusside), an alkylating agent (streptozotocin), and an oxygen free radical generator (alloxan) than mouse and rat islets $(2,5)$. These results implied that interand intraspecies variation in $\beta$ cell resistance to various toxins may affect the progression of $\beta$ cell destruction in IDDM $(1,2)$.

In order to further clarify these interspecies differences, we have presently chosen to study two major lines of cellular defense: the expression of the stress proteins heat shock protein 70 (hsp70) and heme oxygenase (HO) on one hand, and of the antioxidant enzymes catalase and superoxide dismutase (SOD) on the other. Hsp70 is induced by a multitude of stressful situations and is known to rescue cells from misfolding of proteins (6). In a previous study, we observed that intracellular delivery of hsp70 protected rat islets against IL- $1 \beta$-induced inhibition of $\beta$ cell function (7). Both hsp70 and $\mathrm{HO}$ are induced in $\beta$ cells by IL- $\beta$ and may therefore exert protective actions (8-10). Reduced glutathione (GSH) and the antioxidant enzymes SOD and catalase constitute not only the main cellular defence against oxygen free radicals, but also protect against other noxious chemicals and reactive intermediates (11). It has previously been proposed that rodent $\beta$ cells express low levels of antioxidant enzymes and are therefore particularly vulnerable to oxidative stress $(12,13)$. In the present study, we have found species-specific differences in these two major defense systems, which may explain the lower sensitivity to $\beta$ cell damage previously observed in human islets.

\section{MATERIALS AND METHODS}

\section{Islet Isolation and Culture}

Thirty-three human pancreata were excised from heart-beating organ donors, transported to the Central Unit of the $\beta$ Cell Transplant, Brussels, where islets were isolated as previously described (14). The age of the donors was $32 \pm 3$ years (mean \pm SEM; range: 7-64 years). Aliquots of the islet-enriched fraction were examined by electron microscopy $(n=33)$, revealing $4.4 \pm 0.5 \%$ dead cells and $1.6 \pm 0.5 \%$ acinar cells in the preparations. The prevalence of insulin- and glucagon-positive cells was evaluated by light microscopical examination of immunocytochemically stained cells (15), indicating $54 \pm 2 \%$ insulin-positive cells and $10 \pm 1 \%$ glucagonpositive cells. The islet insulin content was 1.52 $\pm 0.10 \mathrm{ng}$ insulin/ng DNA.

After isolation, the human islets were cultured in Ham's F-10 medium containing $6.1 \mathrm{mM}$ glucose and $0.5 \%(\mathrm{w} / \mathrm{v})$ bovine serum albumin. After 2-9 days (4.5 \pm 0.3 days) the islets were sent by air to Uppsala, where they were cultured free-floating in groups of 150-200 islets/dish in RPMI 1640 medium containing $5.6 \mathrm{mM}$ glucose and $10 \%(\mathrm{v} / \mathrm{v})$ fetal calf serum (FCS), with medium change every 2 days (for details on human islet transport and culture see Ref. 14). Rat islets were isolated from male Sprague-Dawley rats (local Uppsala colony), and were cultured in a similar way (16) except for the presence of 11 mM glucose in the RPMI 1640 medium $(16,17)$. Isolated mouse islets were obtained from NMRI mice (B\&K Universal, Sollentuna, Sweden) and were cultured as the rat islets. We have previously shown that functional preservation in RPMI 1640 medium is optimal at $5.6 \mathrm{mM}$ glucose for human islets (14) and at $11 \mathrm{mM}$ glucose for rodent islets $(16,17)$. In some experiments human islets were cultured in RPMI 1640 supplemented with 1 or $10 \%$ FCS, 5.6 or $11 \mathrm{mM}$ glucose, or in Ham's F-10 or Parker 199 media supplemented with $10 \%$ FCS.

\section{Immunoblot Analysis of hsp70 and HO}

Groups of 100 mouse, rat, or human islets were taken directly from different culture conditions or incubated for $30 \mathrm{~min}$ at 37 or $42^{\circ} \mathrm{C}$ and then cultured for an additional $6 \mathrm{hr}$ at $37^{\circ} \mathrm{C}$. The islets were then washed in cold PBS, pelleted, and briefly sonicated in $100 \mu \mathrm{l}$ cold TE (10 mM Tris, 1 mM EDTA). An aliquot was taken for total protein content determination according to Bradford (18), and the remaining sample was precipitated with three volumes of cold acetone. After centrifugation $(5 \mathrm{~min}$ at $12,000 \times \mathrm{g}$ ), protein pellets were solubilized in $30 \mu \mathrm{l}$ SDS-gel sample buffer ( $2 \%$ SDS, $100 \mathrm{mM}$ Tris, $\mathrm{pH} 6.8$, 
$100 \mathrm{mM} \beta$-mercaptoethanol, $0.01 \%$ bromophenol blue, and $10 \%$ glycerol) by boiling for $4 \mathrm{~min}$. Equal amounts $(20 \mu \mathrm{g})$ of protein were then run on $12 \%$ SDS-polyacrylamide gels. After electrophoresis, proteins were electrically transferred to nitrocellulose filters and incubated with rabbit anti-rat HO antibody (StressGen Biotechnologies, Victoria, British Columbia, Canada) or rabbit anti-bovine hsp70 antibody (19) diluted $1: 1000$ in PBS $+5 \%$ fat-free milkpowder. Horseraddish peroxidase (HRP) linked goat anti rabbit Ig was used as a second layer. The immunodetection was performed as described for the ECL immunoblotting detection system (Amersham International, United Kingdom). The intensities of the bands were quantified by densitometry (Beckman DU-62).

\section{Purification and Quantification of hsp70 from Mouse, Rat, and Human Cells}

Hsp70 was purified from approximately $5 \times 10^{7}$ human U937 cells, mouse NIH3T3 cells (both kindly provided by Dr. K. Nilsson, Uppsala university, Uppsala, Sweden), or rat RINm5F cells. All cells were heat-shocked for $60 \mathrm{~min}$ at $43^{\circ} \mathrm{C}$ $3 \mathrm{hr}$ before protein purification. The hsp70 was purified by ATP-agarose affinity chromatography as previously described (20). Protein concentration was determined according to Bradford (18), and equal amounts of protein ( 2 and $10 \mathrm{ng} / \mathrm{lane}$ ) were run on $9 \%$ SDS-polyacrylamide gels. Hsp70 bands were visualized after Western blotting and immunodetection with the anti-hsp70 antibody as described above.

\section{Immunoblot Analysis of Bcl-2}

Human U-266-70 cells and human pancreatic islets were washed in PBS, lysed in TBS, pH 8.0 (25 $\mathrm{mM}$ Tris- $\mathrm{HCl}, 144 \mathrm{mM} \mathrm{NaCl}$ ), with the addition of $0.1 \%$ SDS, $50 \mathrm{mM}$ dithiothreitol (DTT), $0.5 \mathrm{mM}$ phenylmethylsulfonylfluoride (PMSF), $1 \%$ trasylol, $0.5 \%$ desoxycholate (DOC), and $1 \%$ Nonidet P-40 (NP-40). After sonication $3 \times 15$ sec, the lysates were cleared by centrifugation at $17,000 \times g$ for $30 \mathrm{~min}$. The extract ( $15 \mu \mathrm{g} /$ lane) was boiled for $4 \mathrm{~min}$ in sample buffer, run on a $15 \%$ SDS-polyacrylamide gel, and subsequently electrically transferred to a hybond ECL filter (Amersham). The filter was preblocked in TBS containing 5\% nonfat milk and $0.5 \% \mathrm{NP}-40$ for $1 \mathrm{hr}$ before overnight incubation with anti-Bcl-2 antibodies diluted 1:50 (21). HRP-conjugated rabbit anti mouse Ig was used as a second layer.

\section{Transplantation of Human and Rat Islets to Nude Mice}

Duplicate goups of 150-200 cultured human or rat pancreatic islets were implanted under the left renal capsule space (22) of normoglycemic nude (nu/nu) BALB/cBom-nu/nu mice (Bomholtgaard, Ry, Denmark). In parallel, the same number of human and rat islets were frozen in liquid nitrogen and subsequently stored at $-70^{\circ} \mathrm{C}$. Four weeks after transplantation, the mice were killed and the grafts were harvested for stress protein quantification, in parallel with the frozen nontransplanted islets, as described above.

\section{Glucose Oxidation}

Rat and human islets were isolated and exposed for $2 \mathrm{hr}$ to $0,0.1$, and $0.4 \mathrm{mM}$ hydrogen peroxide. Islets were then incubated in triplicate groups of 10 for 90 min in Krebs-Ringer bicarbonate Hepes buffer (without albumin) supplemented with $\mathrm{D}-\left[\mathrm{U}-{ }^{14} \mathrm{C}\right]$ glucose, $16.7 \mathrm{mM}$ nonradioactive glucose and the same concentration of hydrogen peroxide as present during the initial 2 hr. Rates of glucose oxidation were then determined as previously described (14).

\section{Spectrofluorometic Determination of GSH}

Rat, mouse, and human islets, in groups of 500 , were enzymatically digested for 5-10 min at $37^{\circ} \mathrm{C}$ in PBS containing $0.05 \%$ trypsin $+0.02 \%$ EDTA. The cell suspensions were then washed and resuspended in Krebs-Ringer bicarbonate buffer containing $10 \mathrm{mM}$ HEPES, $5.6 \mathrm{mM}$ glucose, $2 \mathrm{mg} / \mathrm{ml} \mathrm{BSA}$, and $40 \mu \mathrm{M}$ Thiolyte reagent, monochlorobimane MC (Calbiochem, La Jolla, CA, U.S.A.) (23). Equal aliquots of the cell suspensions were transferred to 96 -well microtiter plates and incubated for $60 \mathrm{~min}$ at $37^{\circ} \mathrm{C}$. The fluorescence was then quantified every $30 \mathrm{~min}$ in a Perkin-Elmer LS-5B luminescence spectrometer. The excitation and emission wavelengths were 395 and $470 \mathrm{~nm}$, respectively. Emission intensities were calibrated against a 1 -mM GSH standard. After the first determination $(0 \mathrm{~min})$, test agents were added to the cells and the fluorescence was followed for another $180 \mathrm{~min}$. The fluorescence was expressed in percentage of the initial value $(0 \mathrm{~min})$ or as basal fluorescence intensity per microgram of islet cell protein. The presently used method for GSH determination is not fully quantitative. The fluore- 
scense signal may depend upon, for example, variabilities in the rate of uptake and binding to GSH of the fluorescent probe (23). Thus, some caution should be taken when comparing absolute GSH contents of different islet cells. On the other hand, effects of different test substances, expressed as percentages of the initial reading directly before addition of test substances, are validly monitored by this method.

\section{Enzyme Determinations}

The catalase activity of mouse, rat, and human islets was determined using a spectrophotometric method (24). Briefly, islets in groups of 200 were homogenized in $25 \mathrm{mM}$ potassium phosphate buffer, $\mathrm{pH}$ 7.0, and the homogenates were then incubated with $5.9 \mathrm{M}$ methanol and $4.2 \mathrm{mM}$ hydrogen peroxide for $20 \mathrm{~min}$ at room temperature. The reaction was terminated with potassium hydroxide, and Purpald was then added. After $10 \mathrm{~min}$, potassium periodate was added, and the absorbance was measured at $550 \mathrm{~nm}$. Appropriate blanks and formaldehyde-standards were also measured.

Islet SOD activities were measured by the inhibition of the chemiluminescence of luminol, which was induced by superoxide anions produced by the action of xanthine oxidase on xanthine (25). The activity of SOD causing 50\% inhibition of the chemiluminescence was defined as $0.01 \mathrm{U}$.

\section{DNA Nick End-Labeling of Tissue Sections (TUNEL Staining)}

Paraffin embedded sections were deparaffinized and incubated for $15 \mathrm{~min}$ with $20 \mu \mathrm{g} / \mathrm{ml}$ proteinase $\mathrm{K}$. This was followed by a 5 -min exposure to $2 \%$ hydrogen peroxide. After repeated washings with water, each section was incubated at $37^{\circ} \mathrm{C}$ for 60 min with terminal deoxynucleotidyl transferase (10 e.u. $/ 50 \mu \mathrm{l}$ ) and biotinylated deoxyuridine (dUTP) $(0.5 \mathrm{nmole} / 50 \mu \mathrm{l})$ (both from Boehringer-Mannheim, Mannheim, Germany) in transferase buffer ( $30 \mathrm{mM}$ Tris, $\mathrm{pH} 7.2,140 \mathrm{mM}$ sodium cacodylate and $1 \mathrm{mM}$ cobalt chloride). The sections were then repeatedly washed with water, blocked for 10 min with $2 \%$ bovine serum albumin, and washed again with water. Sections were incubated with Vectastain ABC (1:100 avidin, 1:100 biotinylated horseradish peroxidase, in PBS and $0.1 \%$ bovine serum albumin) (Vector Laboratories) for $30 \mathrm{~min}$ at room temperature. After repeated washings in water, the sections

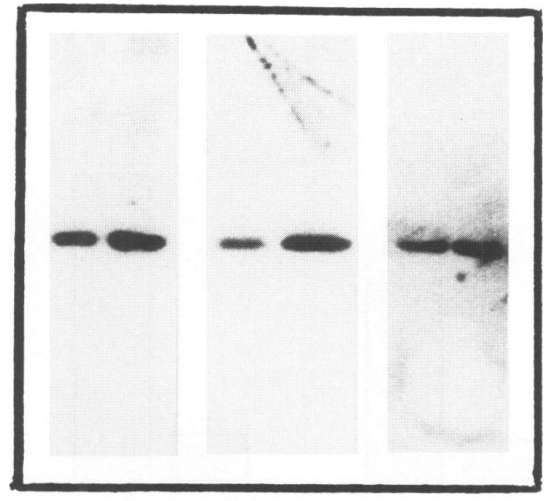

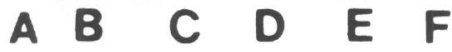

FIG. 1. Binding of anti-hsp70 antibodies to mouse, rat, and human hsp70 in immunoblot experiments

Hsp70 was purified from human U937 cells (Lanes A and $B$ ), mouse NIH3T3 cells (Lanes $C$ and D), and rat RINm-5F cells (Lanes E and F). Two (Lanes A, C, and E) and $10 \mathrm{ng}$ (Lanes B, D, and F) of the purified hsp70 were run on a SDS-polyacrylamide gel, blotted onto nitrocellulose, and incubated with antihsp70 antibodies (19). Binding was quantified using ECL and fluorography.

were developed in 3-amino-9-ethylcarbazole solution $(10 \mathrm{mg} / 50 \mathrm{ml} 20 \mathrm{mM} \mathrm{NaAc}$, pH $5.2+6 \mathrm{ml}$ DMSO) for $10 \mathrm{~min}$ at room temperature, washed in water, and cover slips were applied in aqueous medium.

\section{RESULTS}

\section{Recognition of Rat, Mouse, and Human hsp70 by Anti-hsp70 Antibodies in Immunoblot Experiments}

To ensure identical affinity binding of anti-hsp70 antibodies to rat, mouse and human hsp70 in immunoblot experiments, equal amounts of hsp70 isolated from rat, mouse, and human cells by ATP-agarose affinity chromatography were electrophoresed and blotted onto nitrocellulose filters. As seen in Fig. 1, H13 binding to human hsp70 (Fig. 1, Lanes A and B) was similar to that to mouse hsp70 (Fig. 1, Lanes $C$ and D) and rat hsp70 (Fig. 1, Lanes E and F).

\section{Expression of hsp70 and bcl-2 in Mouse, Rat, and Human Islets in Vitro}

The basal expression of hsp70, as assessed by immunoblot experiments, was high in non- 


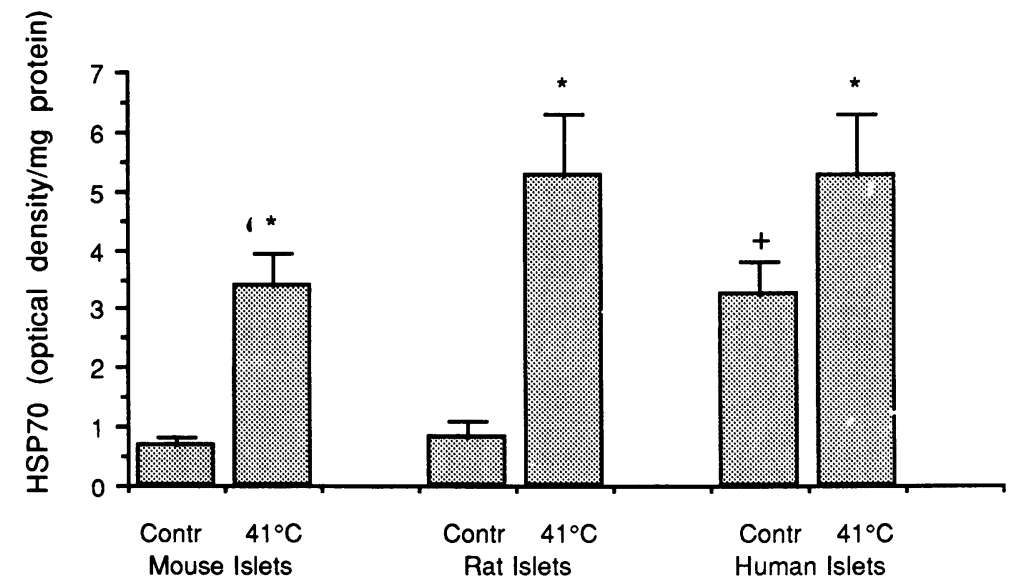

FIG. 2. Contents of hsp70 in control or heat-shocked mouse, rat, and human islets

Precultured mouse, rat, and human islets were incubated for $30 \mathrm{~min}$ at either 37 or $41^{\circ} \mathrm{C}$ and then incubated another $6 \mathrm{hr}$ at $37^{\circ} \mathrm{C}$. Islets were then taken for immunoblot experiments as given in Materials and Methods. Values are means \pm SEM for eight (non-heat-shock) or four (heat-shock) experiments. ${ }^{*} p<0.05$ versus corresponding control islets using Students $t$ test. ${ }^{+} p<0.01$ versus nonheat-shocked mouse or rat islets using ANOVA and Fishers PLSD test. heat-shocked human islets compared with mouse and rat islets cultured for 5-8 days (Fig. 2). After heat-shock, hsp70 was strongly induced in rat and mouse islets, thereby reaching the levels of human islets (Fig. 2). Directly on arrival un Uppsala (Day 0), human islets were taken for hsp70 determinations or cultured for 1 or 7 days at different culture conditions. The hsp70 levels were not affected by culture for 1 or 7 days in RPMI 1640 containing 10\% FCS and $5.6 \mathrm{mM}$ glucose (results not shown). Nor was the expression of hsp70 affected by 7 days of culture in RPMI + 1\% FCS, RPMI $1640+11 \mathrm{mM}$ glucose, Ham's F-10, or Parker 199 media (results not shown). We also investigated the effects of a 24-hr exposure in the presence of cytokines (25 $\mathrm{U} / \mathrm{ml}$ of IL- $1 \beta, 1000 \mathrm{U} / \mathrm{ml}$ of IFN $\gamma$, and 1000 $\mathrm{U} / \mathrm{ml}$ of $\mathrm{TNF} \alpha$ ) on the expression of hsp70 in human islets. It was found that the combination of cytokines did not increase the basal hsp70 level: $2.5 \pm 0.6 \mathrm{o} . \mathrm{d} . / \mathrm{mg}$ protein in control islets and $3.2 \pm 1.0$ in cytokine treated islets $(p>0.05$, $n=4)$. When the same filters were rehybridized for Mn-SOD expression, the cytokines induced a significant increase: $9.6 \pm 1.3 \mathrm{o} . \mathrm{d} . / \mathrm{mg}$ protein in control islets and $15.6 \pm 1.5$ in cytokine treated islets ( $p<0.01$, Student's paired $t$ test, $n=4)$. Expression of bcl-2 was not detected in human pancreatic islets in immunoblot experiments (Fig. 3). U-266-70 cells, which are known to express high levels of bcl-2 (26), were used as a positive control.

\section{Expression of hsp70 in Rat and Mouse Islets After Collagenase Isolation}

Directly after the collagenase isolation procedure, only low levels of hsp70 were expressed in rat and mouse islets (Fig. 4). After 1 and 3 days in culture, however, there was a moderate induction of hsp70 in both types of islets. The hsp70 levels had returned to basal on Day 7 of culture in mouse islets, and to some extent also in rat islets (Fig. 4).

\section{Levels of hsp70 and HO in Rat and Human Islets Transplanted to Nude Mice}

Human islets, which were not transplanted to nude mice but instead frozen before analysis, exhibited increased basal levels of hsp70 compared with rat islets (Fig. 5). After exposure to an in vivo environment for 4 weeks, this difference

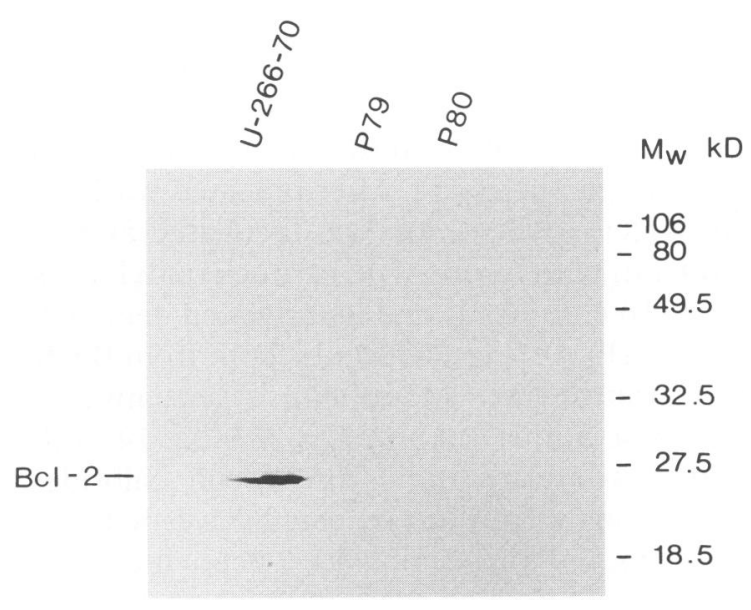

FIG. 3. Expression of bcl-2 in human islets Human islets (pancreata number 79 an 80) and U-266-70 cells were used for immunoblot experiments using anti-bcl-2 antibodies (21). bcl-2 specific binding was visualized by ECL and fluorography. 
FIG. 4. Contents of hsp70 in rat and mouse islets following collagenase isolation

Rat and mouse islets were taken for immunoblot experiments either directly after collagenase isolation or after 1,3 , and 7 days of in vitro culture. hsp70 contents were determined as given in Materials and Methods. Values are means \pm SEM for four observations. ${ }^{*} p<0.05$ versus corresponding control islets on Day 0 for a chance difference using Students $t$ test.

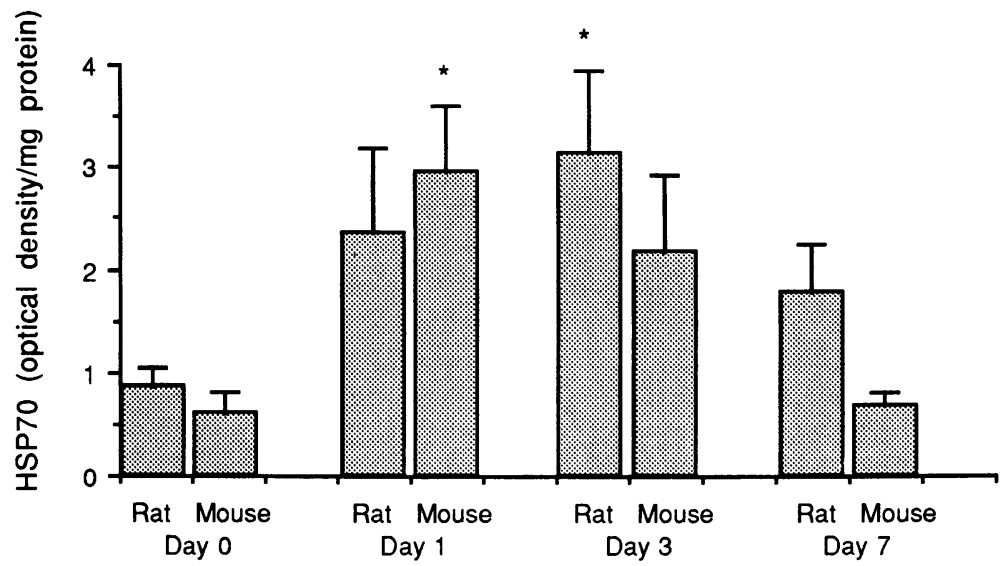

persisted (Fig. 5). The hsp70 levels both in the human and rat islet transplants were lower than those observed in the in vitro cultured islets. However, since we cannot exclude that the islet cell composition and mass was affected by the transplantation procedure, this decrease does not necessarily imply that the hsp70 content was decreased on an islet cell basis. When the same filters were re-exposed to anti-HO antibodies, a completely different pattern was observed. Cultured rat islets expressed high HO levels, which were very much decreased after the 4-week period in vivo (Fig. 5). Also freshly isolated rat islets expressed low contents of HO, which were increased by in vitro culture (results not shown). The HO contents of human islets were low at both conditions (Fig. 5).

FIG. 5. Contents of hsp70 and HO in human and rat islets prior to and after transplantation to nude mice Precultured rat and human islets (5-8 days) were either frozen at $-70^{\circ} \mathrm{C}$ or transplanted under the kidney capsule of nude mice (22). After 4 weeks in vivo, the transplanted islets were retrieved and used for immunoblot experiments. After incubation with anti-hsp70 antibodies, filters were reincubated with $\mathrm{HO}$ antibodies. Results are means \pm SEM for three experiments. ${ }^{* *} p<0.01$ for a chance difference versus cultured rat islets and cultured human islets, respectively, using ANOVA and Scheffes $F$ test. $\star * \star p<0.001$ versus cultured rat islets using ANOVA and Scheffes $F$ test.

\section{Effects of Hydrogen Peroxide, Nitroprusside, and Nicotinamide on Mouse, Rat, and Human Islet GSH Levels}

When comparing the basal GSH levels of rat, mouse and human islet cells before additions of different test substances, no differences were observed (mouse islets: $46.2 \pm 9.7, n=4$; rat islets: 52.1 $\pm 3.0, n=4$; human islets: $61.7 \pm 9.7, n=$ 5 and $p>0.05$, results expressed as fluorescence intensity/ $\mu$ g protein). In rat, mouse, and human islet cells, the contents of GSH decreased in response to hydrogen peroxide (Figs. 6A, 7A, and $8 \mathrm{~A})$. This decrease was maximal already at 0.1 $\mathrm{mM}$ hydrogen peroxide, indicating that the islet GSH-dependent breakdown of hydrogen peroxide was saturated at concentrations lower than $0.1 \mathrm{mM}$. The hydrogen peroxide-induced decrease in GSH after 180 min was only $10-20 \%$ of
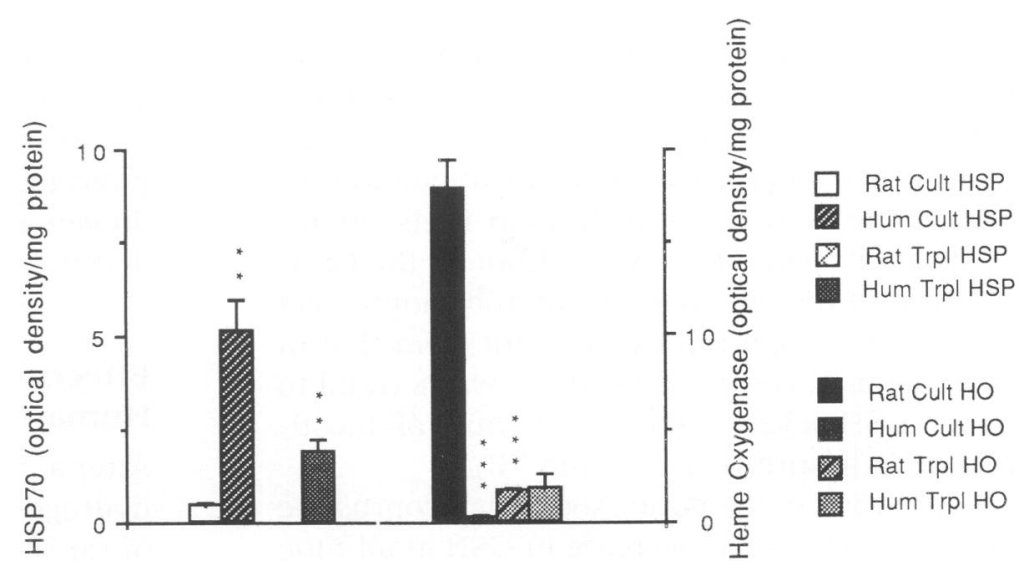

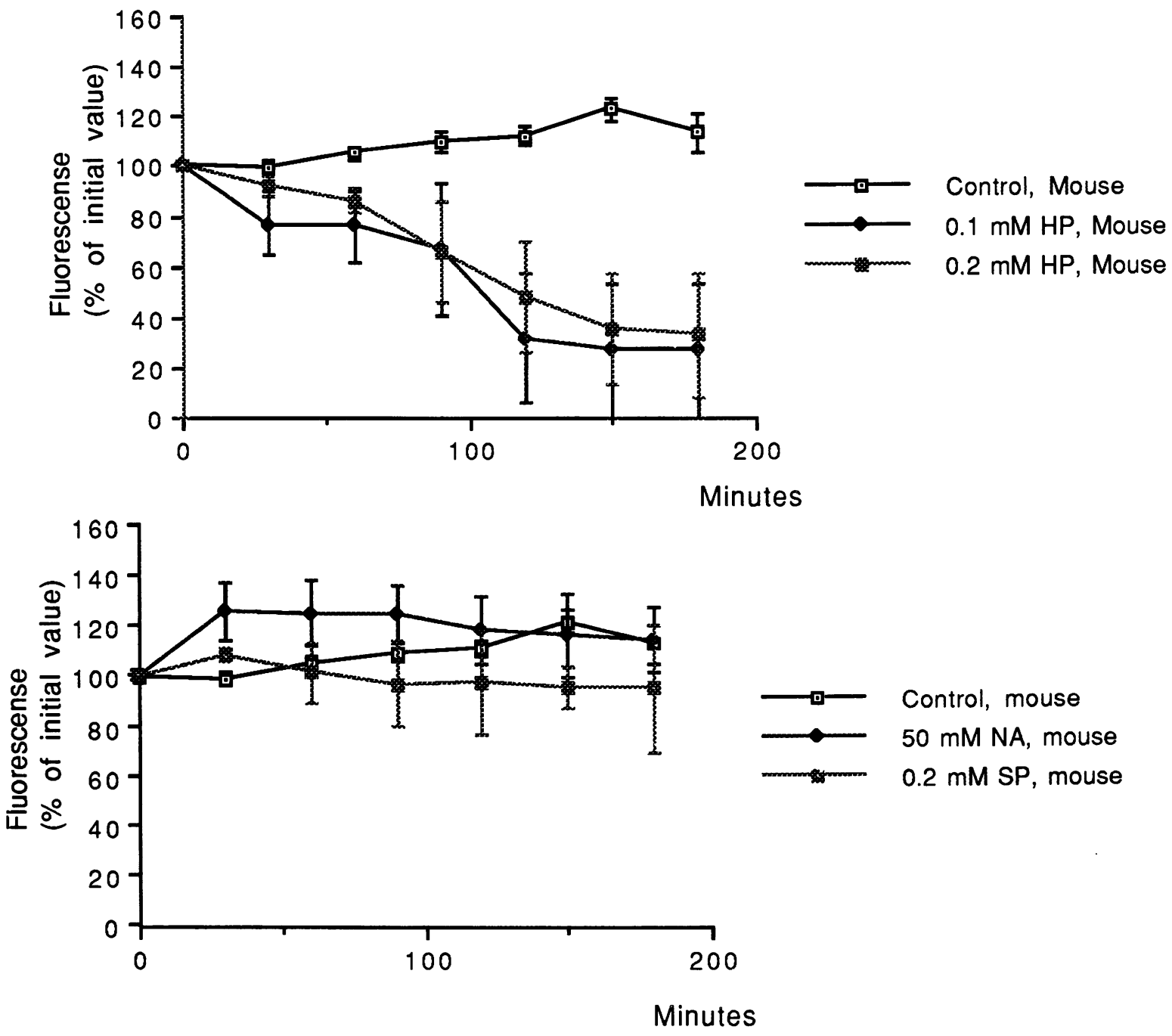

FIG. 6. Effects of hydrogen peroxide, nicotinamide, and nitroprusside on mouse islet GSH contents A suspension of dispersed mouse islet cells was incubated with the fluorescent probe monochlorobimane $(40 \mu \mathrm{M})$ for $60 \mathrm{~min}$ at $37^{\circ} \mathrm{C}$. After the preincubation period, the fluorescence was determined and set to $100 \%$ (initial value). Additions of (A) 0.1 and $0.2 \mathrm{mM}$ hydrogen peroxide (HP) and (B) $50 \mathrm{mM}$ nicotinamide or $0.2 \mathrm{mM}$ sodium nitroprusside (NA and SP) were done directly after Time 0 . The fluorescence was determined every 30 min for 180 min. Values are means \pm SEM for three experiments.

the initial value (Time 0) in human islet cells whereas the decrease was $20-30 \%$ in rat and $60-$ $70 \%$ in mouse islet cells (Figs. 6A, 7A, and 8A).

The free radical scavenger nicotinamide increased the GSH levels in human islets significantly after $30 \mathrm{~min}$ (Fig. 8B). Although the GSHresponse to nicotinamide in rat and mouse islet cells was not significantly different from that of corresponding control cells, there was a trend to higher GSH levels after $30-60 \mathrm{~min}$ of nicotinamine exposure (Figs. 6B and 7B).

The nitric oxide donor sodium nitroprusside induced a significant decrease in GSH at all time points in human islet cells $(p<0.05$, Fig. 8B), and only a nonsignificant trend to lower GSH levels in rodent islet cells (Figs. 6B and 7B). Nicotinamide protected transiently (30-60 $\mathrm{min}$ ) against the hydrogen peroxide- and sodium nitroprusside-induced decrease in human islet cell GSH.

\section{Effects of Hydrogen Peroxide on Rat and Human Islet Glucose Oxidation Rates}

After a 2-hr exposure period to $0,0.1$, or $0.4 \mathrm{mM}$ hydrogen peroxide, the glucose oxidation rates of rat islets were $757 \pm 84,487 \pm 58(p<0.05$ 

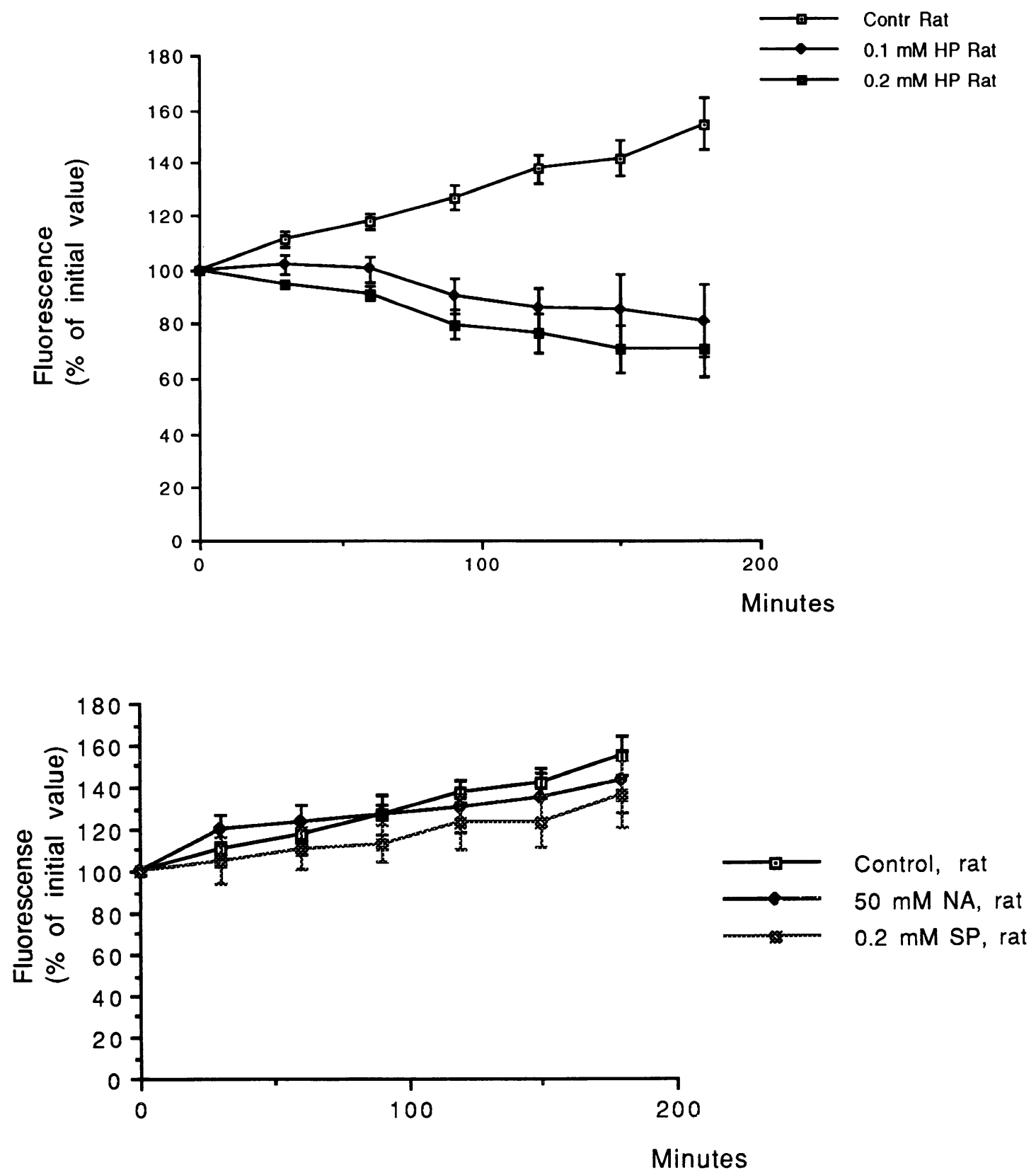

FIG. 7. Effects of hydrogen peroxide, nicotinamide, and nitroprusside on rat islet GSH contents GSH levels of dispersed rat islet cells were determined as given in Fig. 6. Values are means \pm SEM for four experiments.

versus control islets, unpaired $t$ test, $n=5$ ) and $415 \pm 67(p<0.05$ versus control islets, unpaired $t$ test, $n=5$ ) $\mathrm{pmol} / 10$ islets $\times 90 \mathrm{~min}$, respectively. Corresponding values for human islets were $207 \pm 46,235 \pm 13$, and $286 \pm 20$ $\mathrm{pmol} / 10$ islets $\times 90 \mathrm{~min}(p>0.05$ versus control islets, $n=4$ ).

\section{Activities of Catalase and SOD in Rat, Mouse, and Human Islets}

The activities of catalase and SOD were markedly lower in mouse islets than in rat islets (Table 1). On the other hand, corresponding activities of human islets were higher than 

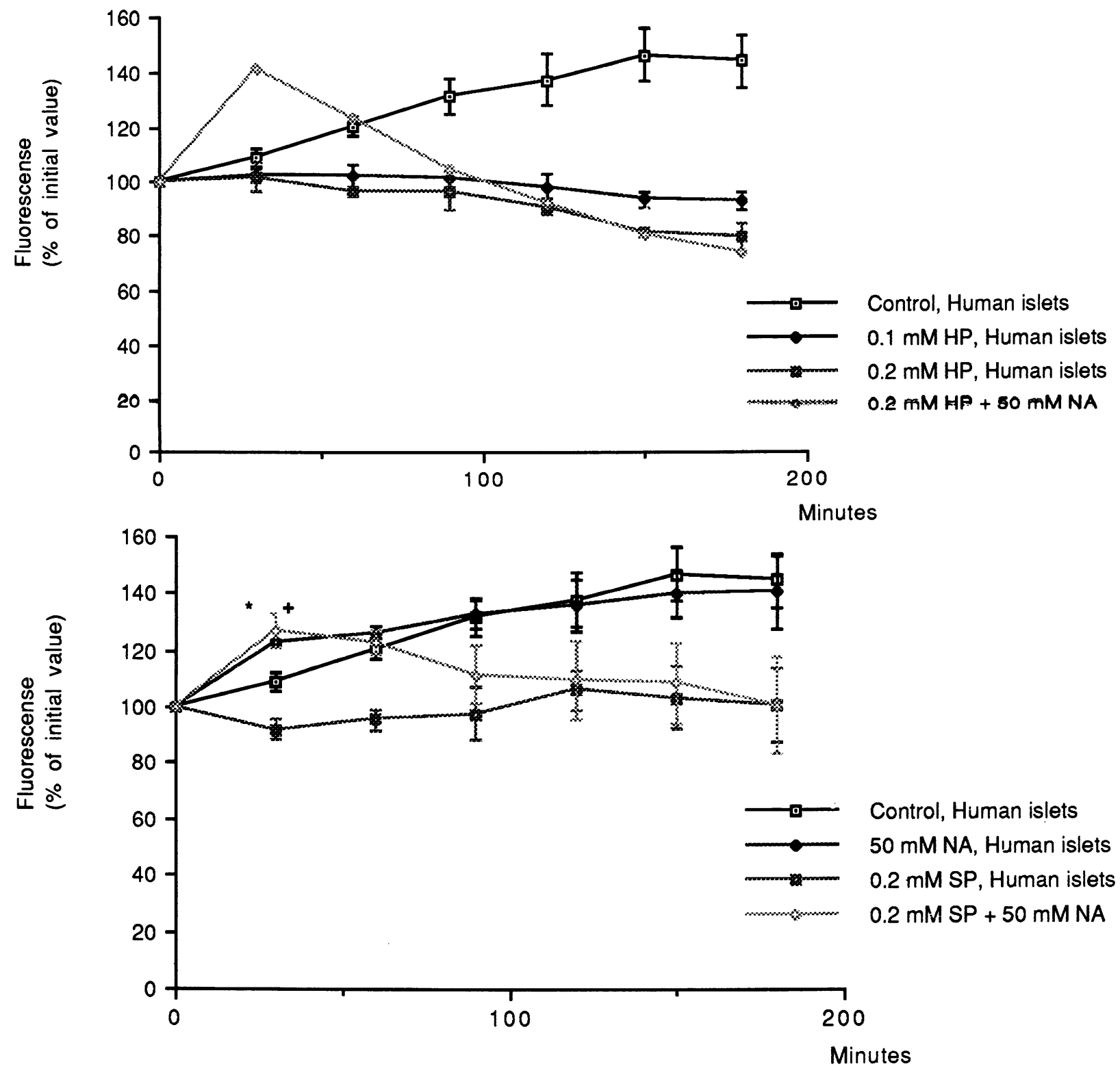

FIG. 8. Effects of hydrogen peroxide, nicotinamide and nitroprusside on human islet GSH contents GSH levels of dispersed human islet cells were determined as given in Fig. 6. Values are means \pm SEM for two to three experiments, except with the $0.2 \mathrm{mM} H P+50 \mathrm{mM}$ NA addition which represents only one observation. ${ }^{*} p<0.05$ for a chance difference between control cells and cells incubated with $50 \mathrm{mM}$ NA using Student's paired $t$ test. ${ }^{+} p<0.05$ for a chance difference between $0.2 \mathrm{mM} \mathrm{SP}$ and $0.2 \mathrm{mM} \mathrm{SP}+50 \mathrm{mM}$ NA using Student's paired $t$ test. At all time points after Time 0 , the $0.2 \mathrm{mM}$ SP group was lower than controls $(p<0.05-0.01$, Student's paired $t$ test).

those of both mouse and rat islets (Table 1). Thus, the catalase activity of mouse islets was only $10 \%$ that of human islets, and the mouse SOD activity was $35 \%$ of that of human islets.

\section{Effects of Streptozotocin on Rat and Human Islet Cell Apoptosis}

Using the TUNEL staining method, apoptotic cells can be identified in a tissue section by a 
TABLE 1. Activities of catalase and superoxide dismutase in rat, mouse, and human pancreatic islets

\begin{tabular}{|c|c|c|}
\hline & $\begin{array}{l}\text { Catalase } \\
\text { (pkat/mg } \\
\text { protein) }\end{array}$ & 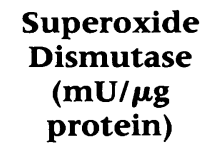 \\
\hline Rat islets & $122 \pm 3.2(4)$ & $7.3 \pm 0.6(4)$ \\
\hline Mouse islets & $19.4 \pm 3.9(4)^{a}$ & $3.2 \pm 0.5(4)^{b}$ \\
\hline Human islets & $197 \pm 11.6(5)^{a}$ & $9.1 \pm 1.7(5)$ \\
\hline
\end{tabular}

Rat, mouse, and human islets were precultured for 5-8 days in RPMI 1640 containing 11.1 (mouse and rat) or 5.6 mM glucose (human). Groups of 200-300 islets were taken for enzyme activity determination as given in Materials and Methods. Results are given as means \pm SEM, with the number of experiments in parentheses. ${ }^{a} p<0.001$ and ${ }^{b} p<0.01$ when comparing with rat islets using Student's $t$ test.

dark-brown nucleus, which is condensed and sometimes fragmented. Apoptotic cells were often observed centrally in large rat islets (Fig. 9A), but not in human islets (Fig. 9D). These accumulations of apoptotic cells probably represent what is usually referred to as "central necrosis" (i.e., death of centrally located cultured islet cells in large islets due to decreased diffusion of oxygen and/or nutrients). In both rat and human islets, no increased rate of apoptosis could be observed after a 2-hr exposure to $0.5,2.0$, or $12 \mathrm{mM}$ streptozotocin compared with control islets (Fig. 9 A, B, D, and E). However, after a 24-hr exposure period at $0.5 \mathrm{mM}$ streptozotocin, a clear increase in the frequency of apoptotic nuclei was observed in rat islets (Fig. 9C). No rat islets could be recovered after $24 \mathrm{hr}$ at 2.0 and 12 $\mathrm{mM}$ streptozotocin (results not shown). There was no apparent increase in apoptosis in human islets exposed for $24 \mathrm{hr}$ to 0.5 and $2.0 \mathrm{mM}$ streptozotocin (Fig. 9F). It was not possible to recover intact human islets after $24 \mathrm{hr}$ at $12 \mathrm{mM}$ streptozotocin (results not shown).

\section{DISCUSSION}

We presently demonstrate that cultured human islets express high levels of hsp70 compared with mouse and rat islets. This may either indicate that human islet cells normally express a high constitutive level of hsp70, or that human islet cells are more stressed in vitro than rodent islet cells. Since the species-related differences in hsp70 levels persisted after 4 weeks in an in vivo environment, and since the hsp70 expression was not affected by different culture conditions, we consider it unlikely that the increased hsp70 expression was due to harsh isolation and transport procedures of the human islets. Indeed, induction of hsp70 in response to stress is known to be transient (6), as presently observed in rat and mouse islets following collagenase isolation, and any stress-induced increase of hsp70 in human islets should therefore have subsided after long-term culture or after 4 weeks in vivo. Although the cellular composition of isolated human islets is slightly different from that of mouse and rat islets $(54 \% \beta$ cells in human islets in the present study versus $77 \% \beta$ cells in cultured mouse islets [27]), this difference would be too small to explain the pronounced increase in hsp70. Our findings, therefore, suggest that the expression of hsp70 under nonstressed conditions is constitutively higher in human islets than in rodent islets. It is noteworthy that the hsp70 expression was not maximal in human islets, since heat-shock induced a moderate increase in hsp70. Although differences in the basal levels of hsp70 among other cells have also been reported $(28,29)$, the present study is to our knowledge the first to demonstrate species-related differences in the basal expression of hsp70 in primary cells.

A completely different pattern of expression was observed with the stress protein HO. This $32-\mathrm{kD}$ protein was low in human islets, both in vivo and in vitro, whereas rat islets expressed high levels in vitro. The finding that there was no induction of $\mathrm{HO}$ in human islets in vitro is further evidence against the idea that culture is severely stressful for these islets. In analogy with hsp70 and its constitutive and cognate form, hsc70, there is one inducible and one constitutive HO gene, denoted HO- 1 and HO-2, respectively (30). Transcription of HO-1 is activated by factors such as heme, heat, UV-light, cytokines, oxidative stress, and heavy metals (30). In rat panceatic islets, $\mathrm{HO}$ is induced by IL- $1 \beta$ and heme (10). Since IL-1 $\beta$ also induces hsp70 and Mn-SOD in these islets $(8,9,31)$, the same transcription factors may be involved in IL- $1 \beta$-induced hsp70, Mn-SOD, and HO expression. It is not clear which environmental factor(s) present during culture induces $\mathrm{HO}$ in rat islets. However, it is possible that the species-related differences in $\mathrm{HO}$ and hsp70 expression may be explained by 

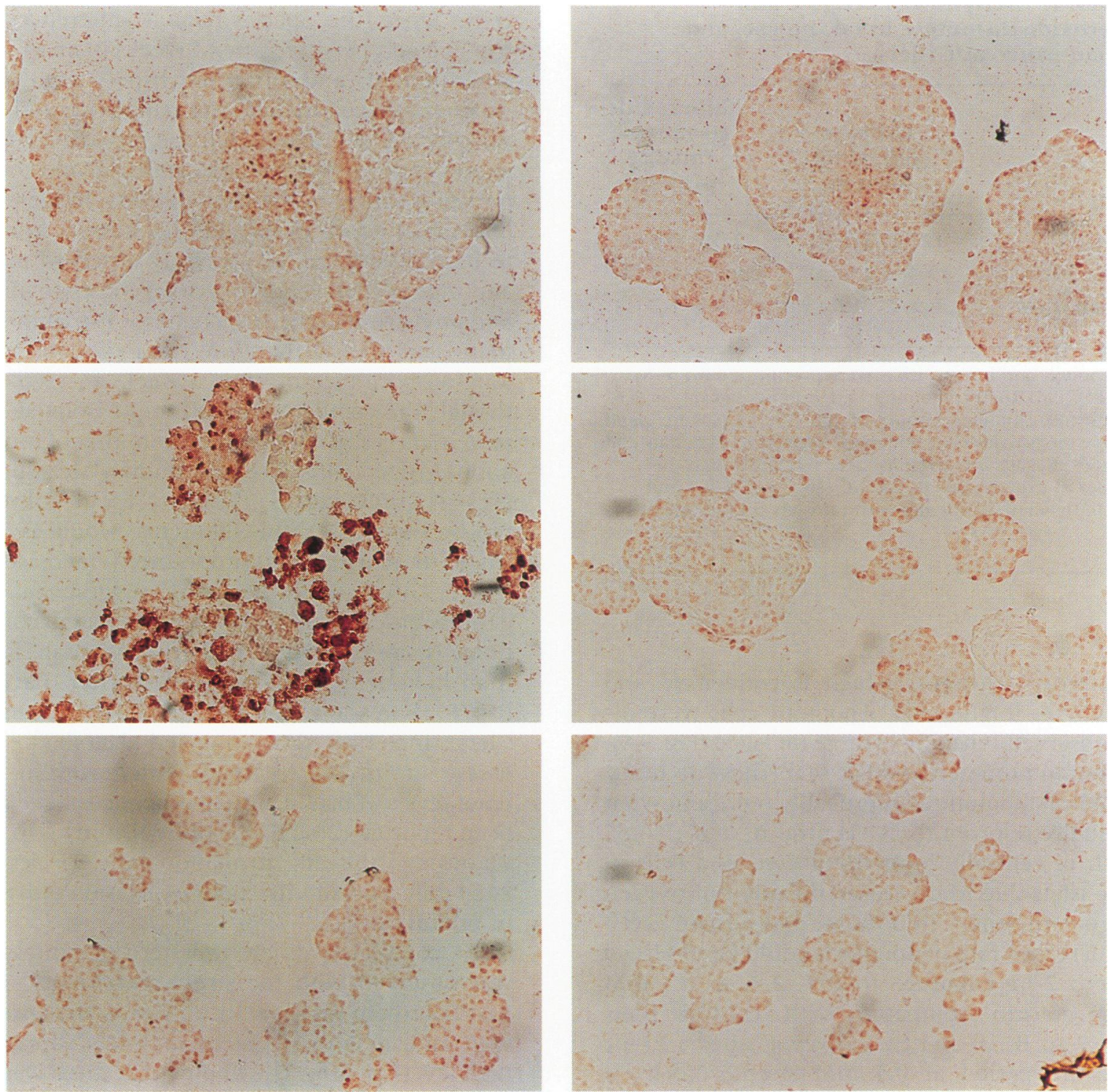

FIG. 9. Effects of streptozotocin on rat and human islet apoptosis

Rat and human islets were treated with different concentrations of streptozotocin for 2 or $24 \mathrm{hr}$.

Apoptotic cells are characterized by condensed and dark-brown nuclei. (A) Control rat islets with an accumulation of centrally located apoptotic nuclei. (B) Rat islets treated with $12 \mathrm{mM}$ streptozotocin for $2 \mathrm{hr}$. A few apoptotic cells can be observed centrally within one large islet. (C) Rat islets treated with $0.5 \mathrm{mM}$ streptozotocin for $24 \mathrm{hr}$. Disrupted islets with a high proportion apoptotic cells can be seen. (D) Human control islets. (E) Human islets exposed to $12 \mathrm{mM}$ streptocotocin for $2 \mathrm{hr}$. (F) Human islets exposed to $2 \mathrm{mM}$ streptocotocin for $24 \mathrm{hr}$. In all three human islet preparations (D-F), there are only a few or no apoptotic cells.

differential transcription factor/regulatory element interaction. For example, it has been shown that the promoter regions of the hsp70 genes in humans and rodents are differently organized. While in the human hsp70 gene there are two promoters, with multiple elements which interact for maximal basal expression, in rodents there is only one promoter, with fewer elements (28).

The putative importance of a constitutively higher level of hsp70 expression in human islet cells is at present unclear. Nevertheless, it is generally agreed that many cell types become less susceptible to heat and to cytotoxic actions of 
cytokines by the pre-induction of heat-shock proteins (6). Moreover, intracellular delivery of hsp70 to rat pancreatic islets counteracted IL-1 $\beta$ induced inhibition of rat islet function (7). In view of these findings, it may be suggested that the increased resistance of human islets to certain noxious agents might, at least in part, be due to the increased hsp70 levels. In this context, it is noteworthy that polymorphic analysis of hsp70Hom genes revealed an association of an extended MHC-haplotype carrying a rare hsp70 allele with IDDM (32).

HO catalyzes the conversion of heme to biliverdin, iron, and carbon monoxide (30). Induction of $\mathrm{HO}$ during stress is thought to lead to a more efficient disposal of heme released by denatured heme-containing proteins. Biliverdin is then converted to bilirubin, which is an efficient oxygen free radical scavenger (33). Thus, $\mathrm{HO}$ induction might also contribute to the defence against oxygen stress (33-35). However, since rat islets in vitro are highly sensitive to the oxygen free radical generator alloxan $(2,13)$, there is no clear correlation between the expression of $\mathrm{HO}$ and protection against oxidative stress in rodent pancreatic islets.

Cells rely mainly on two lines of defence against oxidative stress: GSH-dependent and GSH-independent inactivation of oxygen free radicals. GSH is consumed as a substrate in the glutathione peroxidase-catalyzed conversion of hydrogen peroxide to superoxide and in detoxification reactions catalyzed by glutathione transferase (11). Non-GSH-dependent reactions are catalyzed by catalase and superoxide dismutase leading to the conversion of hydrogen peroxide and superoxide to oxygen and water. By determination of the islet GSH response to hydrogen peroxide, and the activities of catalase and superoxide dismutase, the two lines of defence were presently compared in the islets from the different species. We observed that human islets are less sensitive to oxidative stress than rat islets. This may be ascribed to the higher activity of catalase in human than in rat islets. The finding that mouse islet GSH levels were sharply decreased by hydrogen peroxide and that the activities of catalase and superoxide dismutase were remarkably low, suggests that these islets rely mainly on GSH-dependent antioxidant mechanisms. Rat islets have previously been shown to be more sensitive than mouse and human islets to the oxygen free radical generator alloxan (2). This may indicate that a high glutathione peroxidase activity of mouse islets fully compensates for the low catalase activity. It should also be pointed out that other factors besides antioxidant enzymes may influence the sensitivity to oxidative stress. For example, it can be envisaged that species-specific differences in the rate of uptake of $\beta$ cell toxins may considerably affect the outcome. However, since the sensitivity of rat islets was higher than human islets to hydrogen peroxide, a toxin which should be equally permeable to all cell membranes, different toxin uptake cannot be the sole factor of importance. Interestingly, it was recently reported that the islet cell activities of antioxidant enzymes are lower in female nonobese diabetic mice (NOD-mice) than in males (36). The NODmouse represents a genetic model for IDDM, in which females develop diabetes at a much higher rate than males and oxygen free radicals are thought to damage $\beta$ cells (37), suggesting a causal relationship between the islet cell antioxidative capacity and the development of diabetes.

The nitric oxide generator nitroprusside reduced the islet cell GSH levels less markedly than did hydrogen peroxide. This may indicate that the cellular defence against this free radical does not involve a substantial consumption of GSH and that the higher resistance of human islets against nitric oxide (2) is probably not due to a more efficient GSH-dependent detoxification. On the other hand, it cannot be excluded that sodium nitroprusside generates less free radicals on a molar basis than hydrogen peroxide.

Nicotinamide has been reported to protect against oxidative stress and nitric oxide in rodent islets $(38,39)$. Moreover, we have recently observed that this agent induces a partial protection against the deleterious effects of cytokines on human pancreatic islets (40). In the present experiments, nicotinamide transiently increased, or tended to increase, islet GSH levels in the three species studied. Moreover, the initial decrease in human islet cell GSH in response to hydrogen peroxide and sodium nitroprusside was counteracted by nicotinamide. This is in line with the proposed role of nicotinamide as a weak free radical scavenger (39). It is not clear why $50 \mathrm{mM}$ of nicotinamide did not exert a more long-lasting protection against $0.2 \mathrm{mM}$ of the free radical generators.

It has been proposed that $\beta$ cells undergo apoptosis, which is also referred to as programmed cell death, both in IDDM and NIDDM $(41,42)$. Recently, it was observed that tumorderived $\beta$ cells become apoptotic when exposed to streptozotocin (43). We have presently ob- 
served that centrally located islet cells of large rat islets die from apoptosis, and not from necrosis as previously assumed. Moreover, low doses of streptozotocin induced widespread apoptosis in rat islets, but not in human islets. Apoptosis induced by, e.g., DNA damaging drugs $(44,45)$, growth factor deprivation $(44,45)$, and heat shock (46) can in other cell types be prevented by expression of the bcl-2 gene. The finding that human islet cells do not express bcl-2 implies that the higher resistance of these cell to $\beta$-cell toxins cannot be explained by the activity of this protein.

In conclusion, the present findings support the view that human islet cells constitutively express higher levels of hsp70 and possess a higher antioxidant capacity than rodent islets. These differences may, at least in part, explain the lower sensitivity of human $\beta$ cells to different toxins (2). These marked interspecies differences suggest that it may be of interest to investigate whether similar differences in hsp70 and antioxidant capacity also exist between diabetes-prone individuals and those who are not predisposed to the disease. If this is the case, it may lead to new markers for predisposition to IDDM.

\section{ACKNOWLEDGMENTS}

The excellent technical assistance of C. Göktürk, I.-B. Hallgren, E. Törnelius, E. Forsbeck, A. Nordin, and M. Engkvist is acknowledged. This study made use of human islets prepared by the Central Unit of the $\beta$ Cell Transplant, with financial support of a concerted action in Medical and Health Research of the European Community. The study was also supported by the Swedish Medical Research Council (Grant 12X-9237, associated with the $\beta$ Cell Transplant, European Concerted Action for the Treatment of Diabetes; and Grants 12X-109, 12X-9886, 12X-6538, 12P10151, and 19P-8982), the Juvenile Diabetes Foundation International, the Swedish Diabetes Association, the Novo-Nordisk Insulin Foundation Committee, the Swedish CFN (Forskningsanlag for alternativa metoder), the Family Ernfors Fund, BIOMED concerted action, the Vlaamse Gemeenschap (Grant 9297-1807), and the Belgian Fonds voor Geneeskundig Wetenschappelijk Onderzoek (Grant 3.0057.94). Maria Alice $R$. de Mello is on leave from the Departamento de Educacao Fisica, UNESP, Rio Claro, SP, Brazil. She is the recipient of a postdoctoral fellowship from the Brazilian Research Agency CNPQ.

\section{REFERENCES}

1. Eizirik DL, Sandler S, Palmer JP. (1993) Repair of pancreatic $\beta$-cells, a relevant phenomenon in early IDDM? Diabetes 42: 13831391.

2. Eizirik DL, Pipeleers DG, Zhidong L, Welsh N, Hellerström C, Andersson A. (1994) Major species differences between humans and rodents in the susceptibility to pancreatic $\beta$-cell injury. Proc. Natl. Acad. Sci. U.S.A. 91: 9253-9256.

3. Eisenbarth GS. (1986) Type I diabetes. A chronic autoimmune disease. $N$. Engl. J. Med. 314: 1360-1368.

4. Skyler JS, Marks JB. (1993) Immune intervention in type I diabetes mellitus. Diabetes Rev. 1: 15-42.

5. Eizirik DL, Sandler S, Welsh N, et al. (1994) Cytokines suppress human islet function irrespective of their effects on nitric oxide generation. J. Clin. Invest. 93: 1968-1974.

6. Craig EA. (1985) The heat shock response. CRC Crit. Rev. Biochem. 18: 239-280.

7. Margulis BA, Sandler S, Eizirik DL, Welsh N, Welsh M. (1991) Liposomal delivery of purified heat shock protein hsp70 into rat pancreatic islets as protection against interleukin- $1 \beta$ induced impaired $\beta$-cell function Diabetes 40: 1418-1422.

8. Helqvist S, Polla BS, Johannesen J, Nerup J. (1991) Heat shock protein induction in rat pancreatic islets by recombinant human interleukin $1 \beta$ Diabetologia 34: 150-156.

9. Welsh N, Welsh $M$, Lindquist S, Eizirik DL, Bendtzen K, Sandler S. (1991) Interleukin- $1 \beta$ increases the biosynthesis of the heat shock protein hsp70 and selectively decreases the biosynthesis of five proteins in rat pancreatic islets. Autoimmunity 9: 33-40.

10. Welsh N, Sandler S. (1994) Protective action by hemin against interleukin- $1 \beta$ induced inhibition of rat pancreatic islet function. Mol. Cell. Endocrinol. 103: 109-114.

11. Deneke SM, Fanburg BL. (1989) Regulation of cellular glutathione. Am. J. Phys. 257: L163-L173.

12. Grankvist K, Marklund S, Täljedal I-B. (1981) CuZn-superoxide dismutase, Mn-superoxide dismutase, catalase and glutathione peroxidase in pancreatic islets and other tissues in the mouse. Biochem. J. 199: 393-398.

13. Malaisse WJ, Malaisse-Lagae F, Sener A, Pipeleers DG. (1982) Determinants of the selective toxicity of alloxan to the pancreatic 
B-cell. Proc. Natl. Acad. Sci. U.S.A. 79: 827930.

14. Eizirik DL, Korbutt GS, Hellerström C. (1992) Prolonged exposure of human pancreatic islets to high glucose concentrations in vitro impairs the $\beta$-cell function. J. Clin. Invest. 90: 1263-1268.

15. Pipeleers DG, In't Veld $P$, Van de Winkel $M$, Maes E, Schuit F, Gepts W. (1985) A new in vitro model for the study of pancreatic A and B cells. Endocrinology 117: 806-816.

16. Andersson A. (1978) Isolated mouse pancreatic islets in culture: effects of serum and different culture media on the insulin production of the islets. Diabetologia 14: 397404.

17. Welsh N, Hellerström C. (1990) In vitro restoration of insulin production in islets from adult rats treated neonatally with streptozotocin. Endocrinology 126: 1842-1848.

18. Bradford MM. (1976) A rapid and sensitive method for the quantitation of microgram quantities of protein utilizing the principle of protein-dye binding. Anal. Biochem. 72: $248-$ 254.

19. Margulis BA, Nacharov PV, Tsvetkova OI, Welsh M, Kinev AV. (1991) The characterization and use of different antibodies against the hsp70 major heat shock protein family for the development of an immunoassay. Electrophoresis 12: 670-673.

20. Welch WJ, Feramisco JR. (1985) Rapid purification of mammalian 70000-dalton stress proteins: Affinity of the proteins for nucleotides. Mol. Cell. Biol. 5: 1229-1237.

21. Pezzella F, Tse AG, Cordell JL, Polford KA, Gatter KC, Mason DY. (1990) Expression of the bcl-2 oncogene protein is not specific for the 14:18 chromosomal translocation. Am. J. Pathol. 137: 225-232.

22. Mellgren A, Schnell Landström AH, Petersson B, Andersson A. (1986) The renal subcapsular site offers better growth conditions for transplanted mouse pancreatic islet cells than the liver or spleen. Diabetologia 29: 670-672.

23. Shrieve DC, Bump EA, Rice GC. (1988) Heterogeneity of cellular glutathione among cells derived from a murine fibrosarcoma or a human renal cell carcinoma detected by flow cytometric analysis. J. Biol. Chem. 263: 14107-14114.

24. Johansson LH, Borg LAH. (1988) A spectrophotometric method for determination of catalase activity in small tissue samples. Anal. Biochem. 174: 331-336.

25. Eriksson UJ, Borg LAH. (1991) Protection by free oxygen radical scavenging enzymes against glucose-induced embryonic malformations in vitro. Diabetologia 34: 325-331.

26. Pettersson $M$, Jernberg Wiklund $H$, Larsson L-G, Nilsson K. (1992) Expression of the bcl-2 gene in human multiple myeloma cells lines and normal plasma cells. Blood 79: 495502.

27. Moreira JE, Hand AR, Borg LAH, et al. (1991) Decrease of insulin-containing secretory granules and mitochondrial gene expression in mouse pancreatic islets maintained in culture following streptozotocin exposure. Virchows Arch. 60: 337-344.

28. Greene JM, Larin Z, Taylor ICA, Prentice H, Gwinn KA, Kingston RE. (1987) Multiple basal elements of a human hsp70 promoter function differently in human and rodent cell lines. Mol. Cell. Biol. 7: 3646-3655.

29. Bensaude O, Morange M. (1983) Spontaneous high expression of heat shock proteins in mouse embryonal carcinoma cells and ectoderm from day 8 mouse embryo. EMBO J. 2: 173-177.

30. Stoker R. (1990) Induction of heme oxygenase as a defence against oxidative stress. Free Radic. Res. Commun. 9: 101-112.

31. Borg LAH, Cagliero E, Sandler S, Welsh N, Eizirik DL. (1992) Interleukin- $1 \beta$ increases the activity of superoxide dismutase in rat pancreatic islets. Endocrinology 130: 2851-2857.

32. Pociot F, Rønningen KS, Nerup J. (1993) Polymorphic analysis of the human MHClinked heat shock protein 70 (HSP70-2) and HSP70-Hom genes in insulin-dependent diabetes mellitus (IDDM). Scand. J. Immunol. 38: 491-495.

33. Llesuy SF, Tomaro ML. (1994) Heme oxygenase and oxidative stress. Evidence of involvement of bilirubin as physiological protector against oxidative damage. Biochem. Biophys. Acta 1223: 9-14.

34. Vile GF, Basu-Modak S, Waltner C, Tyrrell RM. (1994) Heme oxygenase 1 mediates an adaptive response to oxidative stress in human skin fibroblasts. Proc. Natl. Acad. Sci. U.S.A. 91: 2607-2610.

35. Raju VS, Maines MD. (1994) Coordinated expression and mechanism of induction of HSP32 (heme oxygenase-1) mRNA by hyperthermia in rat organs. Biochim. Biophys. Acta 1217: 273-280. 
36. Cornelius JG, Luttge BG, Peck AB. (1993) Antioxidant enzyme activities in IDD-prone and IDD-resistant mice: A comparative study. Free Radic. Biol. Med. 14: 409-420.

37. Horio F, Fukuda M, Katoh H, et al. (1994) Reactive oxygen intermediates in autoimmune islet cell destruction of the NOD mouse induced by peritoneal exudate cells (rich in macrophages) but not $\mathrm{T}$ cells. Diabetologia 37: 22-31.

38. Andersen HU, Jørgensen $\mathrm{KH}$, Egeberg J, Mandrup-Poulsen T, Nerup J. (1994) Nicotinamide prevents interleukin-l effects on accumulated insulin release and nitric oxide production in rat islets of Langerhans. Diabetes 43: 770-777.

39. Wilson GL, Patton NJ, McCord JM, Mullins DW, Mossman BT. (1984) Mechanisms of streptozotocin- and alloxan-induced damage in rat $\beta$-cells. Diabetologia 27: 587-591.

40. Eizirik DL, Sandler S, Welsh N, Bendtzen K, Hellerström C. (1994) Nicotinamide decreases nitric oxide production and partially protects human pancreatic islets against the suppressive effects of combinations of cytokines. Autoimmunity 19: 193-198.

Contributed by D. F. Steiner on July 5, 1995.
41. Juntti-Berggren $L$, Larsson $O$, Rorsman $P$, et al. (1993) Increased activity of L-type $\mathrm{Ca}^{2+}$ channels exposed to serum from patients with type I diabetes. Science 261: 86-90.

42. Lorenzo A, Razzabone B, Weir GC, Yankner BA. (1994) Pancreatic islet cell toxicity of amylin associated with type 2-diabetes mellitus. Nature 368: 756-760.

43. Morgan NG, Cable HC, Newcombe NR, Williams GT. (1994) Treatment of cultured pancreatic B-cells with streptozotocin induces cell death by apoptosis. Biosci. Rep. 14: 243250.

44. Vaux DL, Cory S, Adams JM. (1988) Bcl-2 gene promotes haematopoetic cell survival and cooperates with c-myc to immortalize pre-B cells. Nature 335: 440-442.

45. Strasser A, Harris AW, Cory S. (1991) Bcl-2 transgene inhibits $\mathrm{T}$ cell death and perturbs thymic self-censorship. Cell 67: 889-899.

46. Tsujimoto Y. (1989) Stress-resistance conferred by high level of bcl-2 alpha protein in human lymphoblastoid cell. Oncogene 4: 1331-1336. 